\title{
THE PROBLEMS OF ENSURE OF SAFE LABOR CONDITIONS ON WORKPLACES FOR ADHESIVE BONDING
}

\author{
Barbara CIECIŃSKA, Wojciech HOMIK \\ Rzeszow University of Technology
}

\begin{abstract}
:
In the performance a variety of technological operations a human may come into contact with a variety of factors causing deterioration of safety at work. As an example of which is described in article, adhesive bonding operations are requiring use of specific chemicals, which are adhesives. They are produced on the basis of a variety of compounds, often hazardous to human health. Furthermore, adhesive bonding requires a series of preparatory operations such as degreasing or surface preparation with a specific structure and roughness and auxiliary operations such as measurement of the wettability of surface. In this paper are described examples of risks occurring during adhesive bonding, it is a simple way to estimate the risks associated with the performance of operations. The examples of the determination by the producers of chemicals are described which are used in adhesive bonding and fragment of international chemical safety card (ICSC), as a source of information important to the workplace organization and ensuring safety during adhesive bonding.
\end{abstract}

Key words: safety, risk assessment, hazard, adhesive bonding, hardeners, toxic substances

\section{INTRODUCTION}

Accidents at work are somehow encoded in the human industrial activity. According to develop of the industry, used diversity of technology and hundreds of processed and synthesized substances there is an increases of degree of human exposure to injury or loss of life. Assurance a safe working environment becomes an important problem, applied in this connection a number of methods that allow to analyze threats and the development an action plan. In many cases, such as analysis must be made individually, taking into account the specificity of performed activities and used the chemical substances. For such identification often are necessary cards of chemical preparations offered by manufacturers. Information listed in these cards relates to the chemical characteristics of the impacts on the human body, guidelines on storage, procedure in case of contact with the human body. They are necessary to determine safeguard measure applied in workplaces.

The environment is an integral part of the surroundings in which man is functioning. Substances used in industry, used in large quantities may have a negative impact on the environment, including working environment. They can cause occupational diseases or may have an impact on air quality, water quality or soil health benefits. So, now it attaches great importance to the development and implementation of secure technology, and also eliminates the technological processes substances harmful to people. The reasons for doing so are so-called rules cleaner production and applicable standards and regulations. However, not always the specifics of carried out of processes allows the complete elimination of harmful factors of chemical substances which are used in the industry, due to its characteristics allow the formation of the particular condition e.g. surface layer of objects, properties, or design features and perform measurement and analysis. Then, it is important to ensure of maximum safety in the present conditions. In such cases, apply proper work procedures and personnel protective equipment. An example described in this paper is adhesive bonding a widely used way of design elements combining.

\section{GENERAL REQUIREMENTS FOR OPERATIONS OF ADHESIVE BONDING}

Adhesive bonding is the most universal way of bonding. Most materials can be bonded together even if they differ from each other significantly in properties and chemical structure [5]. Bonded may be, for example metal with rubber, with ceramics. Selected should be proper adhesive, adhesive technology and should be taking into account the expected strength of connection $[2,8]$.

However, the bonding process are linked some limitations $[1,13]$ :

- requirements for special equipment - mixers for the preparation of adhesive-bonded composition, holder for adhesive bonding and fastening,

- harmfulness to human health and the environment,

- special safety requirements when using chemicals or specialized equipment.

Adhesive bonding requires the implementation of a number of different operations prior to combining pieces together. Much attention is given to the preparation of the surface before applying the adhesive, and each activity should take place under certain conditions. Sometimes it is necessary to use chemicals and to provide a defined temperature and humidity during curing of the weld. 

12]:

Bonding is carried out according to the scheme $[3,4$,

- degreasing and cleaning - removing dust particles from previous processing operations, lubricants, organic and inorganic contaminants, paints - can be performed in acidic or alkaline baths,

- rinsing and drying - removing residues of cleaning chemical substances, preparing for further operations, removing of liquid through the ventilation or under nitrogen or argon (Fig. 1),

- preparatory treatment - in order to give a specific nature to the top layer, it can be mechanical or chemical, e.g. to give the required roughness surface to improve the mechanical adhesion and forming of the oxide layer. It is also used to remove layer of corrosion, previously used varnishes, adhesives,

- special processing - e.g. laser processing, ozonation or others - used to make special energy state what is the need for proper production of the weld,

- levying of ground, primers and or activators to improve the adhesion,

- application of primers and adhesives,

- composing fastening, fixing, fastening and hardening of the weld.
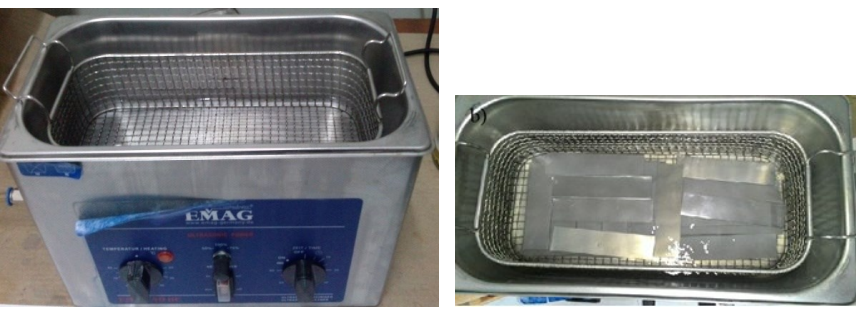

Fig. 1 Degreasing in a bath of acetone under laboratory conditions

\section{RISKS IN ADHESIVE BONDING OPERATIONS}

According to specific operations preceding of adhesive bonding the risk analysis was carried out using the standard method. In this method, should be estimated the potential effects of exposure to harmful $S$ and the probability of its occurrence $P$. Risk $R$ is defined as a product $[7,14,15]$ :

$$
R=S \cdot P
$$

Then, after estimating the $\mathrm{S}$ and $\mathrm{P}, \mathrm{R}$ can be determined based on the guidelines shown in Table 1.

Risk is estimated for particular groups of operations before adhesive bonding and attention is paying to chemical, mechanical and organization of work (Tab. 2-4) [2, 3].

In the adhesion process are also other specific steps that require determination of surface wettability. Wettability characterized suitability of surface to create the adhesive connection. To determine the wettability should be taking the measurements of the contact angle. The measurement is performed on the goniometers by using liquid (Fig. 2), such as distilled water, diiodomethane, alphabromonaphthalene, formamide and other [16].
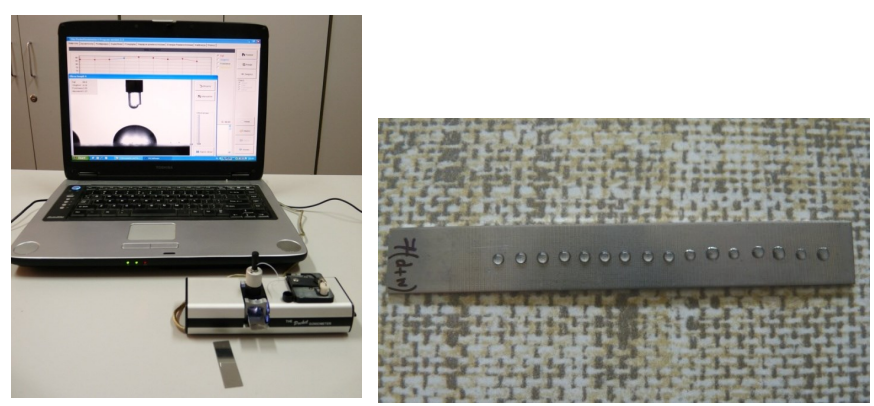

Fig. 2 Measurement of wettability on the goniometer: a) measuring position, b) measuring drops of diiodomethane

Table 1

The rules of risk assessment using the standard method

\begin{tabular}{llll}
\hline $\mathbf{P}$ & $\mathbf{S}$ & & \\
\cline { 2 - 4 } & Small (slight injury) & Medium (serious injuries) & Serious (death) \\
very small & {$[1]$ negligible } & {$[2]$ acceptable } & [3] medium \\
medium & {$[2]$ acceptable } & {$[3]$ medium } & {$[4]$ seriously } \\
big & {$[3]$ medium } & {$[4]$ seriously } & {$[5]$ unacceptable } \\
\hline
\end{tabular}

Source: [14].

Table 2

Risk during cleaning surfaces process

\begin{tabular}{|c|c|c|c|c|c|c|}
\hline \multicolumn{7}{|c|}{ Source of hazards - cleaning and degreasing } \\
\hline Lp. & Hazards & Cause of hazards & Impact on the safety & Effects & Probability & Risk level \\
\hline 1. & $\begin{array}{l}\text { Application of } \\
\text { solvent TRI }\end{array}$ & & $\begin{array}{l}\text { - Carcinogenicity } \\
\text { - Irritates the eyes, skin }\end{array}$ & Health damage & & \\
\hline 2. & $\begin{array}{l}\text { (trichlorethylene) } \\
\text { Application }\end{array}$ & $\begin{array}{l}\text { - Pouring on the } \\
\text { floor, the entrain- }\end{array}$ & $\begin{array}{l}\text { - Vapors may cause drowsi- } \\
\text { ness and dizziness }\end{array}$ & $\begin{array}{l}\text { - Skin , hands or } \\
\text { other body } \\
\text { parts irritation }\end{array}$ & & \\
\hline & of solvent & ment to the sub- & - Flammable & - Eye irritation & & \\
\hline & acetone & strate & - Risk of explosion & - Respiratory & & \\
\hline & & $\begin{array}{l}\text { - Pouring on cloths } \\
\text { and skin }\end{array}$ & $\begin{array}{l}\text { - Irritation of mucous } \\
\text { membranes, eyes, skin } \\
\text { - Vapors may cause }\end{array}$ & $\begin{array}{l}\text { problems } \\
\text { - Serious damage } \\
\text { to health }\end{array}$ & high & unacceptable \\
\hline 3. & $\begin{array}{l}\text { Application } \\
\text { of solvent } \\
\text { petrol }\end{array}$ & $\begin{array}{l}\text { - Spread of vapor } \\
\text { in air }\end{array}$ & $\begin{array}{l}\text { drowsiness and dizziness } \\
\text { - Flammable } \\
\text { - Risk of explosion }\end{array}$ & $\begin{array}{l}\text { Loss of work se- } \\
\text { curity medium }\end{array}$ & & \\
\hline
\end{tabular}


Table 3

Risk during a galvanic baths

\begin{tabular}{|c|c|c|c|c|c|c|}
\hline \multicolumn{7}{|c|}{ Source hazards - galvanic baths } \\
\hline Lp. & Hazards & Cause of hazards & $\begin{array}{c}\text { Impact } \\
\text { on the safety }\end{array}$ & Effects & Probability & Risk level \\
\hline 1. & $\begin{array}{l}\text { Bathing in the acids of } \\
\text { different concentra- } \\
\text { tions }\end{array}$ & & $\begin{array}{l}\text { - Burn the skin, eyes - } \\
\text { Burn the respiratory and } \\
\text { digestive }\end{array}$ & $\begin{array}{l}\text { Health damage } \\
\text { - skin, eyes irritation } \\
\text { - problems with the }\end{array}$ & & \\
\hline 2. & Alkaline bath & $\begin{array}{l}\text { - Pouring on the } \\
\text { floor, entrain- } \\
\text { ment to the } \\
\text { substrate }\end{array}$ & $\begin{array}{l}\text { - Strong corrosive - mu- } \\
\text { cosal irritation or burns, } \\
\text { eyes, skin }\end{array}$ & $\begin{array}{l}\text { respiratory, gastroin- } \\
\text { testinal } \\
\text { - allergies }\end{array}$ & & \\
\hline \multirow[t]{3}{*}{3.} & Bathing in chromates & - Pouring on & - Carcinogenic & $\begin{array}{l}\text { - burns } \\
\text { - serious damage to }\end{array}$ & high & unacceptable \\
\hline & & $\begin{array}{l}\text { cloths and skin } \\
\text { - Spread of vapor }\end{array}$ & $\begin{array}{l}\text { - Mutagenic } \\
\text { - Toxic on the respirato- }\end{array}$ & health & & \\
\hline & & in air & $\begin{array}{l}\text { ry tract } \\
\text {-In case of long expo- } \\
\text { sure - highly allergenic, } \\
\text { corrosive, causing burns }\end{array}$ & $\begin{array}{l}\text { Loss of work security } \\
\text { serious }\end{array}$ & & \\
\hline
\end{tabular}

Table 4

Risk during preparation and applying of adhesive mixture

\begin{tabular}{|c|c|c|c|c|c|c|}
\hline \multicolumn{7}{|c|}{ Source of hazards adhesive bonding } \\
\hline Lp. & Hazards & $\begin{array}{c}\text { Cause } \\
\text { of hazards }\end{array}$ & $\begin{array}{l}\text { Impact } \\
\text { on the safety }\end{array}$ & Effects & Probability & Risk level \\
\hline 1. & $\begin{array}{l}\text { Epoxy } \\
\text { adhesives }\end{array}$ & & $\begin{array}{l}\text { - Allergies } \\
\text { - Skin lesions }\end{array}$ & Health damage & & \\
\hline & & & $\begin{array}{l}\text { - If the composition is, for example } \\
\text { styrene - mutagenic, carcinogenic } \\
\text { - Eye irritation } \\
\text { - Disorders of the digestive system } \\
\text { and kidney function }\end{array}$ & $\begin{array}{l}\text { - skin, eyes irrita- } \\
\text { tion } \\
\text { - problems with } \\
\text { the respiratory, } \\
\text { gastrointestinal }\end{array}$ & & \\
\hline 2. & $\begin{array}{l}\text { Cyanoacrylate } \\
\text { adhesives }\end{array}$ & & - Eyes, skin irritation & $\begin{array}{l}\text { - allergies } \\
\text { - burns }\end{array}$ & & \\
\hline 3. & $\begin{array}{l}\text { Methacrylate } \\
\text { adhesives }\end{array}$ & & $\begin{array}{l}\text { - Headache } \\
\text { - Allergies or skin irritation }\end{array}$ & $\begin{array}{l}\text { - serious damage } \\
\text { to health }\end{array}$ & & \\
\hline 4. & $\begin{array}{l}\text { Polyurethane } \\
\text { adhesives }\end{array}$ & $\begin{array}{l}\text { - Hands con- } \\
\text { tamination }\end{array}$ & $\begin{array}{l}\text { - Flammable } \\
\text { - Toxic due to the presence of } \\
\text { solvents } \\
\text { - Irritating to eyes, skin, respiratory } \\
\text { system } \\
\text { - Carcinogenic }\end{array}$ & $\begin{array}{l}\text { - disorders of } \\
\text { internal organs } \\
\text { - serious damage } \\
\text { to health }\end{array}$ & & \\
\hline 5. & $\begin{array}{l}\text { Adhesives } \\
\text { based on PVC } \\
\text { (poly (vinyl } \\
\text { chloride)) }\end{array}$ & $\begin{array}{l}\text { - Mouth } \\
\text { Or eyes con- } \\
\text { tamination } \\
\text { - Spread }\end{array}$ & $\begin{array}{l}\text { - Flammable } \\
\text { - Toxic due to presence } \\
\text { of solvents }\end{array}$ & $\begin{array}{l}\text { Loss of work } \\
\text { security }\end{array}$ & high & unacceptable \\
\hline 6. & $\begin{array}{l}\text { Adhesives } \\
\text { based on phe- } \\
\text { nolic resins or } \\
\text { phenol- } \\
\text { formaldehyde }\end{array}$ & of vapor in air & $\begin{array}{l}\text { - Mutagenic } \\
\text { - Acute poisoning } \\
\text { - Respiratory } \\
\text { - Loss of consciousness } \\
\text { - Orientation disorders } \\
\text { - Inflammation of the skin }\end{array}$ & serious & & \\
\hline 7. & $\begin{array}{l}\text { The application } \\
\text { of hardeners: } \\
\text {-Z1 } \\
\text { (triethylenetetr } \\
\text { amine) } \\
\text { - with addition } \\
\text { of hydrochloric } \\
\text { acid, sulfuric } \\
\text { acid or phos- } \\
\text { phoric acid }\end{array}$ & & $\begin{array}{l}\text { - Corrosive } \\
\text { - Scalding } \\
\text { - Allergies } \\
\text { and inflammation of the skin }\end{array}$ & & & \\
\hline
\end{tabular}


Measurements made with water do not pose a risk to health, while others mentioned liquids are harmful to human. They can be highly toxic, requiring work in a fume hood, can cause irritation to skin, eyes, cause gastrointestinal symptoms, irritate the respiratory tract (eg. formamide). Diidomethane is irritating to skin and eyes, gastrointestinal tract in case of ingestion, it is believed that it may be carcinogenic $[16,17]$.

\section{SAFETY ASSURANCE}

A careful analysis of composition of the chemicals that are used in bonding, makes it possible to apply appropriate practices. On the label of adhesives can be found information about impact on the environment (Fig. 3 and Fig. 4).
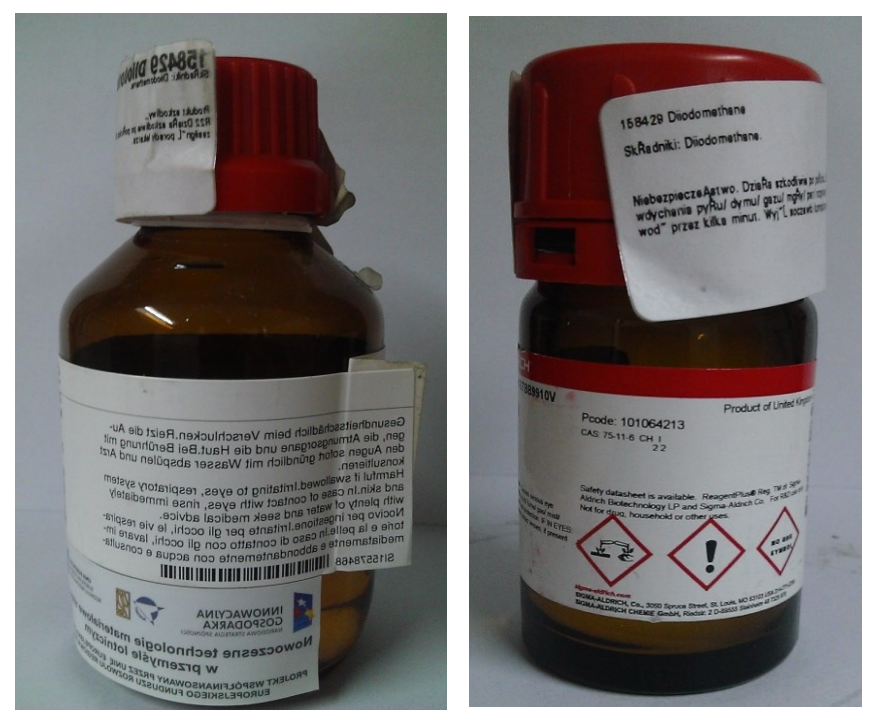

Fig. 3 Examples of markings for measuring liquids (diidomethane)
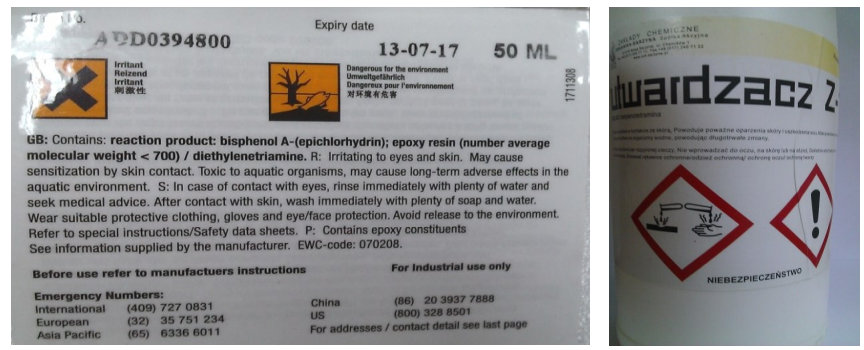

Fig. 4 Example of information about hazard put on the label of: a) adhesives, b) hardener

The best source of data on how to proceed with a chemical is its safety data sheet (Fig. 5). This document contains information about the procedure in case of the occurrence of a variety of situations, such as skin contact, eye contact, ingestion. In addition, there are known substances storage conditions and various other information necessary to assure safe working condition.

To assure safe working conditions is necessary to take many actions directly from the following positions $[9,11]$ :

- personnel equipped with protective clothing (face masks, goggles, gloves, aprons),

- installation of ventilation, fume extraction equipment,

- installation of washing under running water to wash the eyes, showers to rinse chemicals in case of overflowing clothing,

- drain installation for water contaminated of chemicals to collect or filtering (inadmissible direct connection to the sewage system),

- planning the space for waste's containers - contaminated clothes, gloves and empty containers constitute hazardous waste,

- separation space from others stations and transport roads due to possible interference of other (not entitled) persons,

- securing containers with covers.

\begin{tabular}{|c|c|c|c|c|c|}
\hline \multicolumn{6}{|c|}{ ACETONE } \\
\hline \multicolumn{3}{|l|}{$\begin{array}{l}\text { 2-Propanone } \\
\text { Dimethyl ketone } \\
\text { Methyl ketone } \\
\mathrm{C}_{3} \mathrm{H}_{6} \mathrm{O} / \mathrm{CH}_{3} \mathrm{COCH}_{3} \\
\text { Molecular mass: } 58.1 \\
\text { ICSC } \text { o oo } 87\end{array}$} & \multicolumn{3}{|l|}{$\begin{array}{l}\text { CAS * 67-64-1 } \\
\text { RTECS * aL3150000 } \\
\text { UN : } 1090 \\
\text { EC : 606-0o1-oo-8 } \\
\text { April 22, 199- Validated } \\
\text { F, review at IHE: 10/09/89 }\end{array}$} \\
\hline $\begin{array}{l}\text { TYPES OF } \\
\text { HAZARD/ } \\
\text { EXPOSURE }\end{array}$ & \multicolumn{2}{|c|}{$\begin{array}{l}\text { ACUTE HAZARDS/ } \\
\text { SYMPTOMS }\end{array}$} & \multicolumn{2}{|l|}{ PREVENTION } & $\begin{array}{l}\text { FIRST AID/ } \\
\text { FIRE FIGHTING }\end{array}$ \\
\hline FIRE & \multicolumn{2}{|l|}{ Highly flammable. } & \multicolumn{2}{|l|}{$\begin{array}{l}\text { NO open flames, NO sparks, and } \\
\text { No smoking. }\end{array}$} & $\begin{array}{l}\text { Powder, alcohol-resistant foam, } \\
\text { water in large amounts, carbon } \\
\text { dioxide. }\end{array}$ \\
\hline EXPLOSION & \multicolumn{2}{|c|}{ Vapour/air mixtures are explosive. } & \multicolumn{2}{|c|}{$\begin{array}{l}\text { Closed system, ventilation, } \\
\text { explossoon-proof electrical } \\
\text { equipment and lighting, Do NoT } \\
\text { use compressed air for filling } \\
\text { discharging, or handling. }\end{array}$} & $\begin{array}{l}\text { In case of fire: keep drums, etc., } \\
\text { cool by spraying with water. }\end{array}$ \\
\hline \multicolumn{6}{|l|}{ EXPOSURE } \\
\hline -INHALATION & \multicolumn{2}{|c|}{$\begin{array}{l}\text { Sore throat. Cough. Confusion. } \\
\text { Headache. Dizziness. Drowsiness. } \\
\text { Unconsciousness. }\end{array}$} & \multicolumn{2}{|l|}{$\begin{array}{l}\text { Ventilation, local exhaust, or } \\
\text { breathing protection. }\end{array}$} & $\begin{array}{l}\text { Fresh air, rest. Refer for medical } \\
\text { attention. }\end{array}$ \\
\hline •SKIN & \multicolumn{2}{|c|}{ Dry skin. } & \multicolumn{2}{|l|}{ Protective glowes. } & $\begin{array}{l}\text { Remove contaminated clothes. } \\
\text { Rinse skin with plenty of water or } \\
\text { shower. }\end{array}$ \\
\hline •EYES & \multicolumn{2}{|c|}{$\begin{array}{l}\text { Redness, Pain. Blurred vision. } \\
\text { Possible corneal damage. }\end{array}$} & \multicolumn{2}{|c|}{$\begin{array}{l}\text { Safety spectacles or face shield. } \\
\text { Contact lenses should not be worn. }\end{array}$} & $\begin{array}{l}\text { First rinse with plenty of water for } \\
\text { several minutes (remowe contact } \\
\text { lenses if easily possible), then take } \\
\text { to a doctor. }\end{array}$ \\
\hline -INGESTION & \multicolumn{2}{|c|}{$\begin{array}{l}\text { Nausea. Vomiting. (Further see } \\
\text { Inhalation). }\end{array}$} & \multicolumn{2}{|c|}{$\begin{array}{l}\text { Do not eat, drink, or smoke during } \\
\text { work. }\end{array}$} & $\begin{array}{l}\text { Rinse mouth. Refer for medical } \\
\text { attention. }\end{array}$ \\
\hline \multicolumn{2}{|c|}{ SPILLAGE DISPOSAL } & & STORAGE & \multicolumn{2}{|c|}{ PACKAGING \& LABELLING } \\
\hline \multicolumn{2}{|c|}{$\begin{array}{l}\text { Personal protection: self-contained } \\
\text { bresthing apparatus. Ventilation. Collect } \\
\text { leaking liquid in sealable containers. } \\
\text { Absorb remaining liquid in sand or inert } \\
\text { absorbent and remove to safe place. Do } \\
\text { NoT wash away into sewer. Then wash } \\
\text { away with plenty of water. }\end{array}$} & \multicolumn{2}{|c|}{$\begin{array}{l}\text { Fireproof. Separated from strong } \\
\text { oxidants. Store in an area without drain or } \\
\text { sewer acoess. }\end{array}$} & \multicolumn{2}{|c|}{$\begin{array}{l}\text { F symbol } \\
\text { Xi symbol } \\
\text { R: 11-36-66-67 } \\
\text { S: 2-9-16-26 } \\
\text { UN Hazard Class: } 3 \\
\text { UN Packing Group: II } \\
\end{array}$} \\
\hline \multicolumn{6}{|l|}{$1 C C_{t} 0087$} \\
\hline
\end{tabular}


On the security has also affected organization of production process, in this area may prove necessary actions $[6,10]$ :

- correct positioning of measuring stations in the proper ventilation,

- planning transport routes further away from tanks with liquid,

- procedures for supervision and storage of chemicals together with ICSC,

- exclusion of persons which are not connected with bonding,

- storing substances in the original packaging with ICSC,

- assuring appropriate environmental conditions temperature, humidity, ventilation in the context of storage of substances,

- training in safety procedures and knowledge of guidelines, training for emergencies.

\section{CONCLUSIONS}

Occupational risk is defined as a state of security or likelihood of hazard. During the implementation of technological processes indicate the hazards, and in their presence, people express a specific consent. So, there is high possibility to assess the risk as an acceptable or an unacceptable. The concept of occupational risk is associated not only with factors that pose a hazard to human health, but also with those of technical, organizational or human designed to ensure an acceptable level of risk. At this restriction is affected by introduced solutions e.g.:

- technical - installing ventilation systems, screens, covers, etc.,

- organizational - the scope of the method of work and its organization,

- human - selecting the appropriate, qualified staff.

The main criterion of the need for risk assessment are harmful, troublesome or dangerous factors that may occur during the work. Due to the fact that these factors are permanently or temporarily, risk assessment and implementation of measures to ensure human safety should also be carried out periodically. Adhesive bonding is quite specific and are subject to dynamic changes: are developed new structural materials, are produced a new adhesives.

Therefore, risk assessment and maintain it at an acceptable level for human is essential.

The assessment conducted in the research does not require difficult or complicated method usage. Simple statement, that chemicals are used in the technological operations or that the worker has to execute indispensable activities should be the clear sign to take action against risk. In the case of adhesive bonding obtained results were related to real time of worker's exposure on chemicals. In this paper the detailed analysis is presented for only three main fields: surface cleaning processes, galvanic baths and gluing. Conducting these type of job has great range of effect - it can be cleaned large surfaces, in the galvanic baths can be submerge quite big constructions. Large elements are also bonded. Then the worker most of time spends on a risky work place. Ignoring the security measures leads to situation, when the risk is unacceptable and such kind of work places can not be authorized to production.

\section{REFERENCES}

[1] M. Blicharski. Inżynieria powierzchni, Warszawa: Wydawnictwa Naukowo-Techniczne, Warszawa, 2009.

[2] B. Ciecińska. „Ekologia w klejeniu: analiza alternatywnych sposobów wykonywania połączeń klejowych", in Technologia i Automatyzacja Montażu, no. 4, 2012, pp. 50-53.

[3] B. Ciecińska. „Modularyzacja stanowisk klejarskich”, in Zeszyty Naukowe Politechniki Rzeszowskiej (series: Mechanika), no. 284, Rzeszów: Oficyna Wydawnicza Politechniki Rzeszowskiej, 2012.

[4] J. Czaplicki, J. Ćwikliński, J. Godzimirski and P. Konar. Klejenie tworzyw konstrukcyjnych, Warszawa: Wydawnictwa Komunikacji i Łączności, 1987

[5] J. Godzimirski. Tworzywa adhezyjne. Zastosowanie w naprawach sprzętu technicznego, Warszawa: Wydawnictwa Naukowo-Techniczne, 2010.

[6] K. Główczyńska-Woelke. Ocena ryzyka zawodowego, Warszawa: PIP, 2010.

[7] D. Koradecka. Nauka o pracy - bezpieczeństwo, higie na i ergonomia. Warszawa: CIOP, 2000.

[8] J. Kuczmaszewski. Podstawy konstrukcyjne i technologiczne oceny wytrzymałości adhezyjnych połquczeń metali, Lublin: Wydawnictwa Uczelniane Politechniki Lubelskiej, 1995.

[9] J. Lewandowski. Zarzqdzanie bezpieczeństwem pracy w przedsiębiorstwie, Łódź: Wydawnictwo Politechniki Łódzkiej, 2000.

[10] J. Łunarski. Systemy zarzqdzania bezpieczeństwem w przedsiębiorstwie. Rzeszów: Oficyna Wydawnicza Politechniki Rzeszowskiej, 2006.

[11] F. Małysz. BHP w zakładzie pracy. Część I, Warszawa: Wydawnictwo Biblioteczka Pracownicza, 2008.

[12] J. Marczak. Analiza i usuwanie nawarstwień obcych z różnych materiałów metodq ablacji laserowej, Warszawa: BEL Studio, 2004.

[13] B. Rączkowski. BHP w praktyce. Gdańsk: Wydawnictwo Ośrodek Doradztwa i Doskonalenia Kadr, 2009.

[14] I. Romanowska-Słomka and A. Słomka. „Jaką wybrać metodę oceny ryzyka zawodowego?", in Atest Ochrona Pracy, no. 4, 2002, pp. 4-6.

[15] A. Woźny and A. Pacana. Ocena ryzyka zawodowego. Teoria i przykłady, Rzeszów: Oficyna Wydawnicza Politechniki Rzeszowskiej, 2014.

[16] M. Żenkiewicz. Adhezja i modyfikowanie warstwy wierzchniej tworzyw wielkoczqsteczkowych, Warszawa: Wydawnictwo Naukowo-Techniczne, 2000.

[17] ICSC - INTERNATIONAL CHEMICAL SAFETY CARDS: Acetone, Duodomethane, [Online]. Available: www.cdc.gov/niosh

Barbara Ciecińska, PhD, Eng.; Wojciech Homik, DSc, Associate Professor

Rzeszow University of Technology

Faculty of Mechanical Engineering and Aeronautics

Powstańców Warszawy 12, 39-959 Rzeszów, POLAND

e-mail: bcktmiop@prz.edu.pl

whomik@interia.pl 